\title{
USE OF PCR-RFLP FOR GENETIC CHARACTERIZATION OF ECHINOCOCCUS GRANULOSUSISOLATES FROM EGYPT
}

\section{Doaa Ashraf Nassar, Hala SalahElwakil, Hayam Mohammed Ezz Eldin, Hanan Mahmoud Abou-Seri and Khalifa El Sayed Khalifa*}

\author{
Parasitology Department, Faculty of \\ Medicine, Ain Shams University, \\ Abbassia, 115891, Cairo, Egypt \\ Corresponding: \\ Khalifa El Sayed Khalifa \\ Mobile 01118647061 \\ Email: \\ drkhalifa_khalifa@med.asu.edu.eg \\ Received: 20/2/2020 \\ Accepted: 11/3/2020
}

Online ISSN: 2735-3540

\begin{abstract}
:
Background: Cystic Echinococcosis (CE) is a widespread neglected zoonotic disease caused by the larval stage of the dog tapeworm Echinococcus granulosus sensu lato (E. granulosus s. l) that occurs in most parts of the world. Egypt is considered one of the countries where CE represents a public health concern and so far, few studies were done for molecular characterization of E. granulosus.
\end{abstract}

Aim of the work: The aim of the present work was to use polymerase chain reaction-restriction fragment length polymorphism (PCR-RFLP) targeting mitochondrial NADH dehydrogenase subunit 1 (nad1) for genetic characterization of Egyptian isolates of $E$. granulosus to infer the most probable transmission patterns.

Subjects and methods: Fifty Hydatid Cyst Fluid (HCF) and/or germinal layer samples (19 human, 23 camels, and 8 pigs) were collected from hydatid cysts. DNA was extracted from protoscolices and/or germinal layers from each individual cyst and used as template to amplify nad1 gene (1071-1078 bp). The amplification products were then digested with the restriction endonuclease Haemophilus influenza (HinfI) enzyme.

Results: Two RFLP patterns were obtained, pattern I in $95.2 \%$ of samples (12 human, 21 camel and 7 pig samples) with three fragments of 115, 218, and 738 bp and pattern II in $4.8 \%$ (2 human samples) with two fragments of 1035 and $36 \mathrm{bp}$. In total, $85.7 \%$ of human and $100 \%$ of camel and pig samples shared the same digestion pattern I, while pattern II appeared exclusively in two human cases out of the 14 typed (14.3\%).

Conclusion: These results indicate that camels and pigs are crucial in the life cycle of E. granulosus in Egypt, although other animals may play a role.

Keywords: Echinococcus granulosus genotyping, Nad1 gene, (HinfI) enzyme

\section{INTRODUCTION}

Echinococcus granulosus sensu lato (E. granulosus s. l.) larval stage (metacestode) is the causative agent of Cystic Echinococcosis (CE), which is a zoonotic disease considered to be a re-emerging disease in several countries worldwide including Africa and Middle East ${ }^{(1)}$. CE causes great economic loss in livestock through condemnation of infected organs (mainly liver) and can be responsible for a life-threatening infection in humans ${ }^{(2)}$. The World Health Organization (WHO) has included $\mathrm{CE}$ on the list of Neglected Zoonotic Diseases, for which efforts to significantly reduce transmission by 2020 are to be prioritized ${ }^{(3)}$. 
E. granulosus as a species, has extensive phenotypic and genotypic variations, which vary in morphology, life cycle patterns and host specificity. The most common intermediate hosts are farm animals, such as sheep, goats, swine, camels, horses, and cattle, as well as mule deer ${ }^{(4)}$. Worldwide, sheep frequently present the highest infection rate and are considered the epidemiologically most relevant intermediate hosts ${ }^{(5)}$. While camels are the main intermediate hosts known from Sudan, the arid parts of northern East Africa, most of the Middle East and parts of central Asia and western China $^{(6)}$. Pigs are the intermediate hosts in South America and some parts of Africa $^{(7)}$, a small number of infections have been recorded in cattle in Sudan and Italy ${ }^{(8)}$.

Multiple approaches have been proposed for E. granulosus species differentiation including phenotypic characterization by morphology (phenotypes or phenotypic variants), intermediate host specificity, developmental rate, and infectivity to humans (biological variants), biochemical and isoenzyme characterization, or genotypic characterization (genotypes or molecular variants) ${ }^{(9)}$.

Although morphological and biological studies have provided extremely useful information for species identification, these features are considered variable and may be influenced by host and environmental factors and may not reflect differences at the genetic level ${ }^{(10)}$. They can also be affected by the low number of parasites and morphological similarity. So, molecular identification of Echinococcus species infecting humans has been developed to avoid these problems ${ }^{(11)}$.

Genetic characterization of $E$. granulosus populations is crucial for the better understanding of the transmission patterns of the parasite between definitive hosts and intermediate mammalian hosts and assists significantly in the diagnosis and control of $\mathrm{CE}^{(12)}$. It also has a significant impact on the taxonomy of the parasite and epidemiology of echinococcosis, as well as for the drug design and development of vaccines ${ }^{(13)}$. Various techniques have focused on the molecular characterization of E. granulosus, targeting nuclear as well as mitochondrial genes of the parasites ${ }^{(14)}$. Mitochondrial genes have been used widely in population genetics to elucidate phylogenies, as it experiences high mutation and low recombination rates and thus best reflects population genetic structure, population differentiation, and species relationships $^{(15)}$. Moreover, mitochondrial DNA is reported to be more powerful than nuclear DNA within E. granulosuss.l.in constructing phylogenetic relationships among closely related species, because of its rapid sequence evolution ${ }^{(16)}$. Large data sets derived from mitochondrial genomes, also have the potential to resolve problematic issues in Echinococcus taxonomy ${ }^{(17)}$.

A variety of different molecular methods have been used to study genetic variability of Echinococcus spp targeting mitochondrial genome, including random amplified polymorphic DNA-PCR (RAPD$\mathrm{PCR})^{(18)}$, polymerase chain reactionrestriction fragment length polymorphism (PCR-RFLP) (14, 19\&20) and multilocussequence genotyping ${ }^{(21 \& 22)}$.

Although, sequencing approach is the gold standard for genotyping assays, it is costly and cannot be practiced on a routine basis especially in developing countries, where the disease is mostly prevalent ${ }^{(19)}$. PCR-RFLP involves the specific recognition of the genome that has been purposefully chosen and reveals nucleotide variation at enzyme specific sites in the amplified fragments ${ }^{(10)}$. It is a simple and rapid method, which has minimal requirements in terms of quantity of target $\mathrm{DNA}^{(14)}$.PCRRFLP has been used extensively to characterize strain groupings within $E$. granulosus and to detect DNA polymorphism ${ }^{(10,14,17 \& 19)}$. However, the 
results of PCR-RFLP should be indigenously interpreted, due to occurrence of unexpected mutations (nucleotide change/insertion or deletion) in parasite genome $^{(14)}$.

\section{AIM OF THE WORK:}

The aim of the present study was to use PCR-RFLP targeting mitochondrial NADH dehydrogenase subunit 1 (nad1) for genetic characterization of Egyptian isolates of $E$. granulosus to infer the most probable transmission patterns.

\section{SUBJECTS AND METHODS:}

The study was performed on human and animal hydatid cyst fluid (HCF) samples during the period from June 2018 to August 2019. In total, 50 samples were included in the study including 19 human, 8 pigs and 23 camels. During this period, no hydatid cysts from sheep slaughtered in Cairo Abattoir were reported.

\section{Collection of samples:}

\section{Human isolates:}

They were collected from Abdominal Ultrasonography Unit of Tropical Medicine department, Kasr El-Aini Hospital, Cairo University, and from departments of Tropical Medicine, General Surgery and Cardiothoracic Surgery, Faculty of Medicine, Ain Shams University. The 19 patients had confirmed $\mathrm{CE}$ by $\mathrm{HCF}$ examination, 18 samples were collected after PAIR (Percutaneous-Aspiration-InjectionReaspiration) technique of liver cysts. One sample was obtained after surgical removal of a pulmonary cyst.

Animal isolates:

They were collected from Cairo abattoir and consisted of 31 samples including 23 pulmonary camel and 8 hepatic pig cysts.

\section{Parasitological study:}

The HCF was examined microscopically for the presence of protoscolices to determine the cyst fertility. Protoscolices were washed several times in saline and stored at $-20{ }^{\circ} \mathrm{C}$ till further use.

\section{Molecular study analysis}

DNA extraction

Genomic DNA was extracted from protoscolices using "QIAamp ${ }^{\circledR}$ DNA Mini Kit" (Qiagen, Hilden, Germany) according to manufacturer's specifications.

\section{PCR of the nad1 gene}

For molecular identification, PCR amplification was performed as described by ${ }^{(23) .}$ A $1071-1078$ bp fragment including the complete nad1 gene was amplified using a forward primer: 5' TATTAAAAATATTGAGTTTGCGTC-3' and a reverse primer: 5' TCTTGAAGTTAACAGCATCACGA T 3'. PCR was performed in a final volume of 50 $\mu 1$ containing $1 \mathrm{x}$ GoTaq Master MixPCR buffer ( $\mathrm{pH} 8.5$ ), $2 \mathrm{mM} \mathrm{MgCl} 2,200 \mu \mathrm{M}$ of each dNTP, 2.5 U DNA Hot Start polymerase enzyme, $1 \mu \mathrm{M}$ of each primer, and $10 \mu \mathrm{l}$ of the total DNA. Thermal reactions were performed with Initial hot start at $95^{\circ} \mathrm{C}$ for 2 minutes, followed by 35 cycles of denaturation at $94{ }^{\circ} \mathrm{C}$ for 30 seconds, annealing at $55{ }^{\circ} \mathrm{C}$ for 30 seconds, and extension for 90 seconds at $72{ }^{\circ} \mathrm{C}$. Final extension for 5 minutes at $72{ }^{\circ} \mathrm{C}$ was done.PCR products were visualized by separation on a $2 \%$ agarose gel stained with ethidium bromide. In each run negative and positive controls were included.

PCR-RFLP of the nad1 gene:

Haemophilus influenza (HinfI) restriction endonuclease enzyme was used to digest purified PCR product of the nad1 gene ${ }^{(19)}$. PCR products were digested for 1-3 hours according to the manufacturer's instruction (Promega). Restriction fragments were visualized by gel electrophoresis through a 
$2 \%$ agarose gel stained with ethidium bromide. PCR-RFLP bands were defined by their molecular weights estimated from the size standards and by using a standard curve graphed using Microsoft Excel program. Polymorphisms were scored for presence $(+)$ or absence (-) of the bands.

\section{Ethical consideration:}

An oral consent was obtained from the patients after explaining the aim of the study to them. The study was approved by the Research Ethics Committee, Faculty of Medicine, Ain Shams University according to the regulations of Ministry of Higher Education.

\section{RESULTS:}

HCFs were collected from 19 patients and 23 camels, while germinal layers were collected from 8 pigs.

\section{Human samples}

The $19 \mathrm{CE}$ human cases included 10 (52.6\%) males and $9(47.4 \%)$ females. Participants' age ranged from 10 to 60 years, with a median age of 36 years. $79 \%$ of human cases complained from right hypochondrial pain, while $21 \%$ experienced pulmonary symptoms such as coughing, chest pain or dyspnea. Regarding the site of the hydatid cysts among CE cases, 95\% (18 samples) were from the liver, while $5 \%$ (one sample) was from the lung. Microscopic examination of human HCFs in 18 (94.7\%) out of the 19 human samples revealed the presence of hooks, while one sample (5.3\%) was negative by microscopic examination and proved positive after germinal layer examination.

Animal samples:

Microscopic examination of HCFs of all camel samples revealed the presence of protoscolices. HCFs of all pig samples were negative and protoscolices were revealed by examination of the germinal layer

\section{PCR-RFLP:}

Amplification of the E. granulosusnad1 gene was successful in 46 (92\%) samples; 16 human, 22 camel and 8 pig producing the expected 1071-1078 bp band on agarose gel (figure 1), while 4 (8\%) samples; 3 human and one camel were negative. Out of the 46 successfully amplified samples, 42 were digested with HinfI constituting two digestion patterns (table 1). Pattern I in 95.2 $\%$ of samples (12 human, 21 camel and 7 pig samples)with three fragments of 115,218 , and 738 bp and pattern II in $4.8 \%$ (2 human samples) with two fragments of 1035 and 36 bp (figure 2). In total $85.7 \%$ of human and $100 \%$ of camel and pig samples shared the same digestion pattern I, while pattern II appeared exclusively in two human cases $(14.3 \%)$ out of the 14 typed (table 2 ).

Table (1): RFLP patterns of nad1 of E. granulosus from human, camel and pig samples

\begin{tabular}{|c|c|c|c|c|c|c|c|c|}
\hline \multirow[t]{2}{*}{ Sample } & \multirow[t]{2}{*}{ N. } & \multicolumn{6}{|c|}{$\begin{array}{l}\text { Restriction with HinfI } \\
\text { (bp) }\end{array}$} & \multirow[t]{2}{*}{ Digestion patterns } \\
\hline & & 36 & 115 & 218 & 738 & 1035 & 1071 & \\
\hline \multirow[t]{3}{*}{ Human } & 12 & - & + & + & + & - & - & I \\
\hline & 2 & + & - & - & - & + & - & II \\
\hline & 2 & - & - & - & - & - & + & Undigested \\
\hline \multirow[t]{2}{*}{ Camel } & 21 & - & + & + & + & - & - & I \\
\hline & 1 & - & - & - & - & - & + & Undigested \\
\hline \multirow[t]{2}{*}{ Pig } & 7 & - & + & + & + & - & - & I \\
\hline & 1 & - & - & - & - & - & + & Undigested \\
\hline
\end{tabular}


Table (2): Percentages of agreements of RFLP patterns from human, camel and pig samples

\begin{tabular}{|c|c|c|}
\hline $\begin{array}{c}\text { Digestion } \\
\text { patterns }\end{array}$ & Isolates & Percentage \\
\hline \multirow{2}{*}{ I } & Human & $85.7 \%(12 / 14)$ \\
\cline { 2 - 3 } & Camel & $100(21 / 21)$ \\
\cline { 2 - 3 } & Pig & $100(7 / 7)$ \\
\hline II & Human & $14.3 \%(2 / 14)$ \\
\hline
\end{tabular}

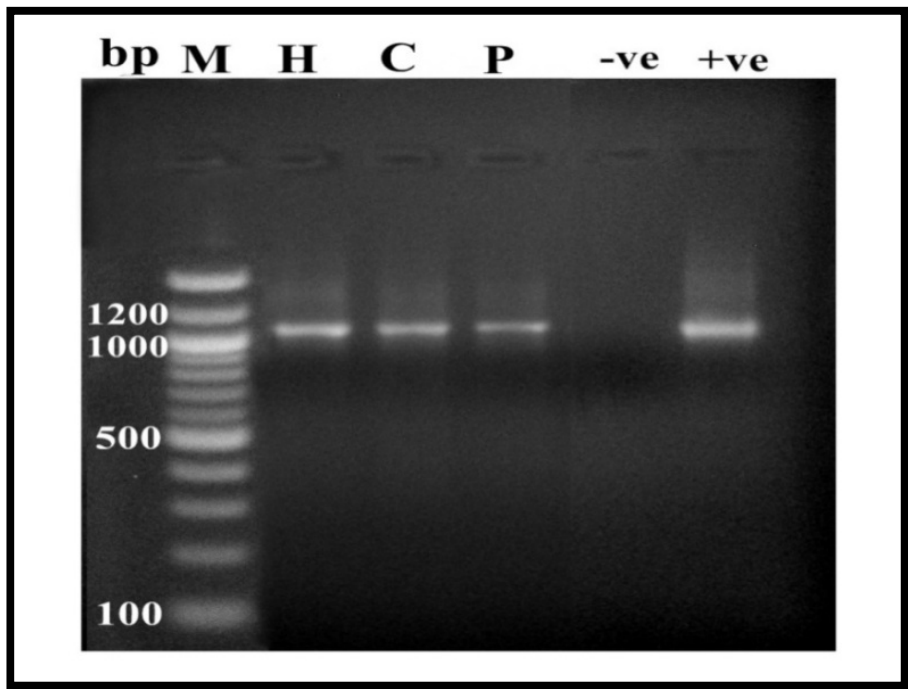

Figure (1): An Ethidium bromide stained agarose gel electrophoresis (2\%) showing the PCR amplification products of E. granulosus nad1 gene. Lane M: DNA marker (100 bp); lane H: human sample, lane C: camel sample, lane P: Pig sample, lane -ve: Negative control (without DNA template); lane +ve: Positive control of E. granulosus showing a DNA fragment of the expected size (1071-1078 bp).

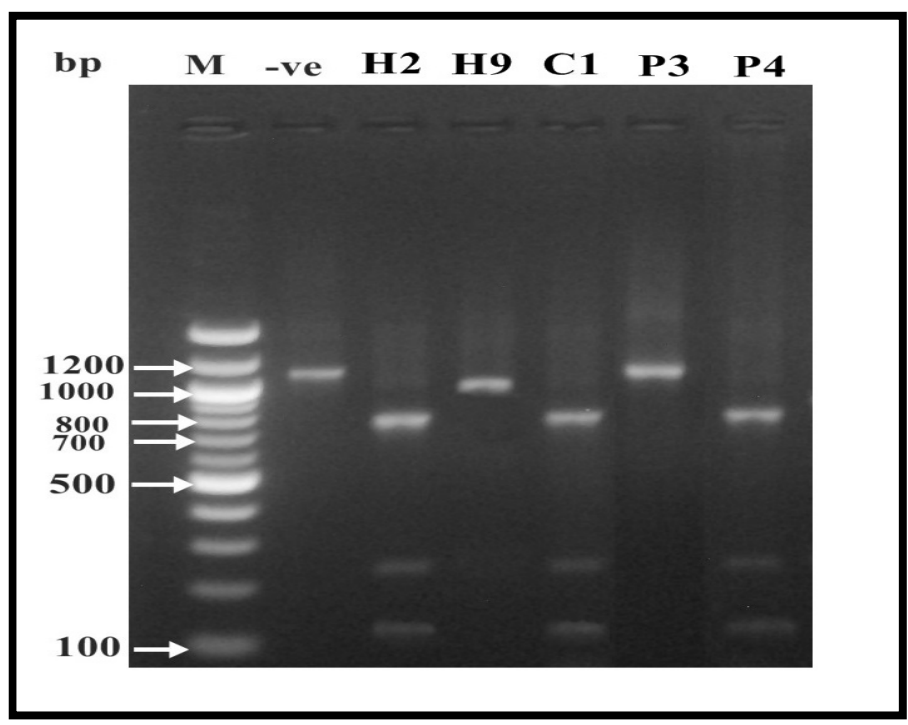

Figure (2): An ethidium bromide stained 2\% agarose gel showing RFLP patterns of E. granulosus nad1 gene after digestion with HinfI restriction enzyme. Lane 1: (M) 100 bp-molecular marker, lane 2: -ve undigested PCR product (1071-1078 bp); lane 3: from human sample (H2) with restriction pattern I; lane 4: from a human sample (H9) with restriction pattern II (the 36 bp band is not seen in the standard gel); lane 5: from a camel sample (C1) with restriction pattern I; lane 6: from pig sample (P3) showing undigested band; lane 7: from pig sample (P4)with restriction pattern I. 


\section{DISCUSSION:}

E. granulosus larval stage is the cause of $\mathrm{CE}$ populations is crucial for the better understanding of the transmission patterns of the parasite between definitive hosts and intermediate mammalian hosts and assists significantly in the diagnosis and control of $\mathrm{CE}^{(\mathbf{1 2})}$.In the present study, PCR-RFLP targeting the mitochondrial nadl genetic marker was used for genetic characterization of human, camel and pig Egyptian isolates. In total 50 samples; 19 human, 8 pigs and 23 camels of confirmed CEwere enrolled in the study. Amplification was successful in $46(92 \%)$ out of the 50 collected samples; 16 human, 22 camel and 8 pig, while 4 (8\%) samples; 3 human and one camel were negative. Targeting variable bp sequences, several investigators have amplified E. granulosus nad1 gene with varying success rate ${ }^{(19,20,22 \& 23)}$. The negative results in the various studies might be due to presence of inhibitory factors in the HCF, paraffin sections and serum or technical problem in the $\mathrm{PCR}^{(22)}$.

In the present study, two patterns were generated after digestion with HinfI, pattern Iin $95.2 \%$ of samples (12 human, 21 camel and 7 pig samples)with three fragments of 115,218 , and 738 bp and pattern II in $4.8 \%$ (2 human samples) with two fragments of 1035 and $36 \mathrm{bp}$. In total, $85.7 \%$ of human and $100 \%$ of camel and pig samples shared the same digestion pattern I, while pattern II appeared exclusively in two human cases out of the 14 typed $(14.3 \%)$. These results indicate that camels and pigs are crucial in the life cycle of E. granulosus in Egypt. Although in the present study, we failed to collect hydatid cysts from other animals slaughtered in Cairo Abattoir, $14.3 \%$ of human cases under study would probably get the infection via dogs acquired the infections from these animals.

The predominance of G6 camel strain in Egypt has been previously documented by several investigators $^{(21,26,27 \& 28)}$. This may be

due to the fact that most camels for human consumption in Egypt are imported from Sudan and are the source of E. Canadensis in Egypt $^{(27)}$. In Sudan, several studies reported the predominance of G6 in camels, goats, and cattle as well as humans in different geographical areas examined ${ }^{(20 \& 29)}$.

In Egypt, a study using multilocus sequence typing targeting nuclear (actin II) and mitochondrial cytochrome c oxidase subunit I (cox1) and nad1 genes found G6 in 26 of the 28 camel cysts, 3 of 7 sheep cysts and the 2 buffalo derived cysts. G1 was found in one cyst from a camel and 4 of 7 cysts from sheep ${ }^{(21)}$. On the other hand, other researchers found G1 common in humans, camels and sheep in Egypt ${ }^{(30)}$. Another study used PCR-RFLP technique based on AluI restriction enzyme showed that the highest genetic similarity was observed between human and sheep isolates $(100 \%)$ followed by human and camel isolates, and pig and camel isolates (66.7\%), while the lowest was observed between human and pig isolates (42.9\%). They reported that the sheep strain is the most relevant strain related to humans ${ }^{(31)}$. Genotype G1 is the most prevalent genotype worldwide, possibly due to the wide range of intermediate hosts, which facilitates higher circulation in the environment ${ }^{(12,32)}$.

It is worth to note that 4 out of the 46 successfully amplified samples were not digested by HinfI restriction enzyme used, this may be due to absence of the enzyme's restriction site due to nucleotide polymorphism. The genetic diversity of G6 African and Middle Eastern isolates has been previously documented ${ }^{(33)}$. The genetic diversity of G1 E. granulosus global isolates was also recorded ${ }^{(32)}$. This result signifies the necessity of using more than one restriction enzyme to build an algorithm for the interpretation of the results of PCRRFLP. The results should be also interpreted endogenously at the level of geographical 
region or country due to occurrence of unexpected mutations (nucleotide change/ insertion or deletion) in parasite genome ${ }^{(14)}$.

In conclusion, the present study as with other studies revealed that camels and pigs are crucial animals in the life cycle of $E$. granulosus in Egypt. However, other animals may play a role.

\section{REFERENCES}

1. Moro P and Schantz PM.(2009): Echinococcosis: a review. Int J Infect Dis, 13:125-133.

2. Zhang T, Yang D, Zeng Z, Zhao W, Liu A, Piao D, et al. (2014): Genetic Characterization of Human-Derived Hydatid Cysts of Echinococcus granulosus Sensu Lato in Heilongjiang Province and the First Report of G7 Genotype of E. canadensis in Humans in China. PLoS ONE, 9(10): e109059.

3. WHO (2010): Working to overcome the global impact of Neglected Tropical Diseases: First WHO Report on Neglected Tropical Diseases. World Health Organization, Geneva.

4. Otero-Abad and Torgerson PR. (2013): A systematic review of the epidemiology of echinococcosis in domestic and wild animals. PLoSNegl Trop Dis, 7(6):e2249.

5. Grosso G, Gruttadauria S, Biondi A, Marventano S and Mistretta A (2012): Worldwide epidemiology of liver hydatidosis including the Mediterranean area. World J Gastroenterol, 18: 1425-1437.

6. Deplazes P, Rinaldi L, Alvarez Rojas CA, Torgerson P, Harandi MF, Romig T, et al. (2016): Global distribution of alveolar and cystic echinococcosis. In: Thompson, A. (Ed.), Echinococcus and Echinococcosis, (95): 315-494.

7. Sanchez E, Caceres O, Naquira C, Miranda E, Samudio F and Fernandes O. (2012):Echinococcus granulosus genotypes circulating in alpacas (Lama pacos) and pigs (Sus scrofa) from an endemic region in
Peru. Mem Inst Oswaldo Cruz, (107)275278.

8. Dinkel A, Njoroge EM, Zimmermann A, Wälz M, Zeyhle E, Elmahdi IE, et al. (2004): A PCR system for detection of species and genotypes of the Echinococcus granulosus-complex, with reference to the epidemiological situation in eastern Africa. Int J Parasitol, 34:645-653.

9. Bart JM, Bardonnet K, Elfegoun MC, Dumon H, Dia L, Vuitton DA and Piarroux R. (2004): Echinococcus granulosus strain typing in North Africa: comparison of eight nuclear and mitochondrial DNA fragments. Parasitol, 128: 229-234.

10. Bowles J and McManus DP. (1993): Molecular variation in Echinococcus. Acta Trop, 53: 291-305.

11. Dybicz M, Gierczak A, Dabrowska J, Rdzanek $Ł$ and Michałowicz B. (2013): Molecular diagnosis of cystic echinococcosis in humans from central Poland. Parasitology International, 62(4): 364-367.

12. Romig T, Ebi $\mathrm{D}$ and Wassermann $\mathrm{M}$. (2015): Taxonomy and molecular epidemiology of Echinococcus granulosus sensu lato. Vet Parasitol, 213:76-84.

13. McManus DP (2013): Current status of the genetics and molecular taxonomy of Echinococcus species. Parasitol, 140 (13): 1617-1623.

14. Spotin A, Gholami S, Nasab AN, Fallah E, Oskouei MM, Semnani V, et al. (2015): Designing and conducting in silico analysis for identifying of Echinococcus spp. with discrimination of novel haplotypes: an approach to better understanding of parasite taxonomic. Parasitol Res, 114 (4): 15031509.

15. Wang J, Wang N, Hu D, Zhong X, Wang S, Gu X, Peng X and Yang G (2014): Genetic diversity of Echinococcus granulosus in southwest China determined by the mitochondrial NADH dehydrogenase subunit 2 gene. Sci World J, 867839. doi: $10.1155 / 2014 / 867839$. 


\section{Doaa Ashraf Nassar, et al.,}

16. Nejad MR, Jahani SS, CheraghipK, Nazemallhoseini ME, Taghi PN and Zali MR.(2012): Hydatic cyst prevalence in slaughtered animals, A neglected health problem. Paramed Sci J, 3(3):25-29.

17. Nakao M, Li T, Han X, Ma X, Xiao N, Qiu J, et al. (2010): Genetic polymorphisms of Echinococcus tapeworms in China as determined by mitochondrial and nuclear DNA sequences. Int J Parasitol, 40:379385.

18. Sharbatkhori M, Mirhendi H, Harandi MF, Rezaeian M, Mohebali M, Eshraghian M, et al. (2010): Echinococcus granulosus genotypes in livestock of Iran indicating high frequency of G1 genotype in camels. Exp Parasitol, 124(4):373-379.

19. Chaâbane-Banaoues R, Oudni-M'rad M, M'rad S, Amani H, Mezhoud H and Babba H. (2016): A novel PCR-RFLP assay for molecular characterization of Echinococcus granulosussensulato and closely related species in developing countries.Parasitol Res, 115:3817-3824.

20. Ahmed ME, Salim B, Grobusch MP and Aradaib IE.(2018): First molecular characterizationof Echinococcus granulosus(sensustricto) genotype 1 among cattlein Sudan. BMC Vet Res, 14(1):36.

21. Amer S, Helal IB, Kamau E, Feng Y and Xiao L. (2015): Molecular Characterization of Echinococcus granulosus SensuLato from Farm Animals in Egypt. PLoS ONE, 10(3):e0118509.

22. Moradi M, Meamar AR, Akhlaghi L, Roozbehani M, and Razmjou E. (2019): Detection and genetic characterization of Echinococcus granulosus mitochondrial DNA in serum and formalin-fixed paraffin embedded cyst tissue samples of cystic echinococcosis patients. PLOS ONE, 14(10): e0224501.

23. Huttner $M$, Nakao $M$, Wassermann $T$, Siefert L, Boomker JD, Dinkel A, et al. (2008): Genetic characterizationand phylogenetic position of Echinococcus felidis (Cestoda: Taeniidae)from the African lion. Int J Parasitol, 38:861-868.
24. Sadjjadi SM. (2006): Present situation of echinococcosis in the Middle East and Arabic North Africa. Parasitol Int. 55: 197202.

25. Nejad MR, Hoseinkhan N, Nazemalhosseini K, Abdinia E and Zali MR. (2007): An analysis of hydatid cyst surgery in patients referred to hospitals in Khorram Abd, Lorestan during 2002-2006. Int J Parasitol, 3: 29-33

26. Aaty HEA, Abdel-Hameed DM, AlamEldin YH, El-Shennawy SF, Aminou HA, Makled SS and Darweesh SK. (2012): Molecular genotyping of Echinococcus granulosus in animal and human isolates from Egypt. Acta Trop, 121(2):125-128.

27. Barghash SM, El Sayed RA, El-Alfy NM, Abou-Elnour BM, El-Kattan AM and Sadek AM. (2017): Prevalence and molecular identification of Echinococcus granulosusin humans and slaughtered animals in Egypt. EJBPS, 4(9):34-42.

28. El Tonsy M; Fikry A; Aminou H ; Hassanin O and Abdelhafiz H. (2018): Antigenic and genotypic characterization of Echinococcus granulosus larval isolates from Egypt. Parasitoluni j, 11(1):44-51.

29. Ibrahim K, Romig T, Kern P and Omer RA. (2011): A molecular survey on cystic echinococcosis in Sinnar area, Blue Nile state (Sudan). Chin Med J, 124:2829-2833.

30. Abd El Baki MH, El Missiry AM, Aaty HE, Mohamad AA and Aminou HA. (2009): Detection of G1 genotype of human cystic echinococcosis in Egypt. J Egypt Soc Parasitol, 39:711-721.

31. Tawfeek GM, Elwakil HS, Awad NS, ElHoseiny L, Thabet HS, Sarhan RM, Darweesh SK and Anwar WA (2009):Genetic Variability of Antigen B among Echinococcus granulosus Egyptian Isolates.Korean J Parasitol. 47(3): 259-264. DOI: $10.3347 / \mathrm{kjp} .2009 .47 .3 .259259$

32. Kinkar L, Laurimäe T, Acosta-Jamett G, Andresiuk V, Balkaya I, Casulli A, et al. (2018): Global phylogeography and genetic diversity of the zoonotic tapeworm Echinococcus granulosus sensu strict 
genotype G1. Int J Parasitol, 48(9-10):729742.

33. Addy F, Wassermann M, Kagendo D, Ebi D, Zeyhle E, Elmahdi IE, et al. (2017): Genetic differentiation of the G6/7 cluster of Echinococcus canadensis based on mitochondrial marker genes. Int $\mathrm{J}$ Parasitol, 47(14), 923-931. doi:10. 1016/j. ijpara. 2017.06.003.

استخدام تفاعل البلمرة التسلسلي- الرفلبيات للتوصيف الجينى لعزلات المشوكة الحبيبية من مصر

دعاء أشرف نصار, هالة صلاح الوكيل , هيام محمد عزالدين, حنان محمود ابوسريع, خليفة السبد خليفة"

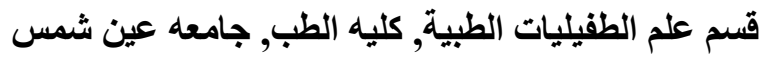

المقدمة :داء الاكياس المائيه هو مرض حيو اني المنشأ مهمل على نطاق واسع ناتج عن الطور اليرقي لدودة المشوكه

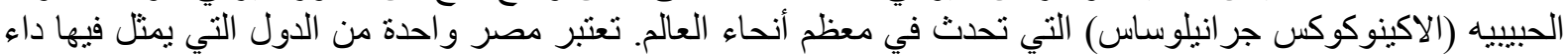

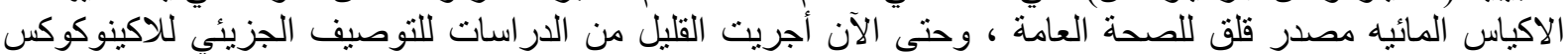
جر انيلوساس.

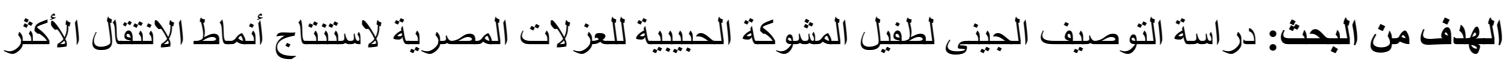

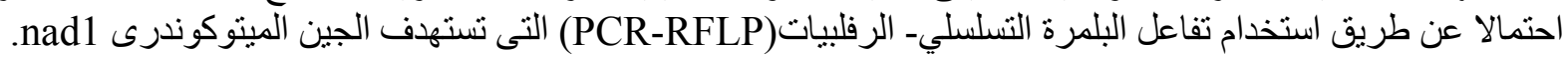

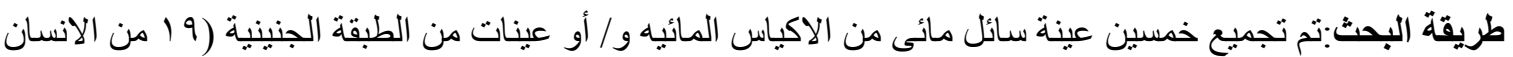

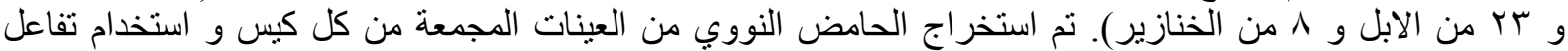
البلمرة التسلسلي- الرفلبيات الذى يستهذف جين nad-1 ثم بعد ذلك هضم المنتجات المنضخمة باستخدام إنزيم

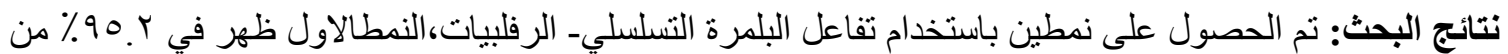

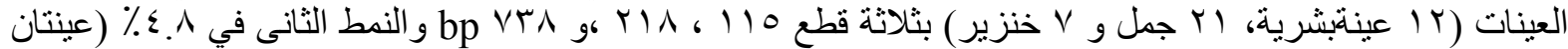

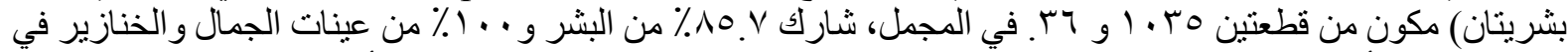

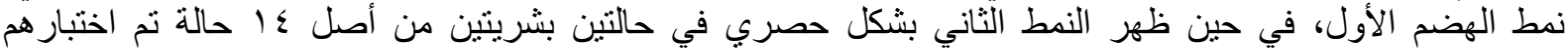
$(\%) \leqslant . r)$

الاستنتاج: تشير هذه النتائج إلى أن الإبل والخنازيرضرورية في دورة حباة هذا الطفيل في مصر، على الرغم من أن الحيو انات الأخرى قد تلعب دوراً. 